\title{
Et bofællesskab og en bevægelse: en antropologisk analyse af økosam- fundsaktivisme på tværs af skalaer
}

Anette Høite Hansen, ph.d.-stipendiat, Institut for Antropologi, Københavns Universitet

Der sker i disse år en stcerk stigning i grcesrødders engagement for en boredygtig omstilling af samfundet. Den mest synlige og studerede form for civilsamfundets engagement er klassisk aktivistiske bevagelser med klare politiske dagsordener. I senere år har samfundsvidenskabelig litteratur dog rettet sit fokus mod en anden type engagement baseret på livsstilsbevagelsers interesse for hverdagspraksis og de indsatser, der udføres af såkaldte hverdagsmagere og praktivister. Hvor studier af livsstilsbevogelser fokuserer på individuel boredygtig handling, omhandler denne artikel også kollektive indsatser, hvor den boeredygtige livsstil praktiseres med det sigte at skabe et velfungerende foellesskabher eksemplificeret gennem kvalitative studier af økosamfund.

Indledning

I senere år har en lang liste af grønne organisationer på hver deres måde arbejdet for at sikre en indsats for den omstilling af samfundet og ændring af borgeres adfærd, der skal føre til en reduktion af den globale opvarmning ${ }^{1}$. Flere af disse initiativer så dagens lys eller fik øget opmærksomhed i perioden efter COP15 i 2009; FN's klimakonference der ikke indfriede forventningerne til international handling på klimaområdet. De lokale initiativer blev igangsat af både kommuner og civilsamfund, der således begyndte at markere sig stærkere med visioner og indsatser (Hoff og Strobel 2013). Mange af initiativerne fokuserer på borgernes rolle og muligheder for at ændre på både den politiske dagsorden og den individuelle adfærd, med blandt andet det overordnede formål at sænke udledningen af $\mathrm{CO}_{2}$. På trods af opblomstringen af grønne organisationer, diskuteres det fortsat både politisk og i den offentlige debat af hvem og hvordan, der bør tages ansvar for at foretage de nødvendige handlinger og sikre den altafgørende reduktion af den globale opvarmning. Er det det internationale samfund, de nationale regeringer, de lokale kommuner eller den enkelte borger, der har ansvar for at $\mathrm{CO}_{2}$-udledningen reduceres (DR Radio 2018; Scavenius 2016)? Nyere studier viser, at der er opstået en særlig interesse

\footnotetext{
${ }^{1}$ Eksempelvis Omstilling Nu, adskillige fødevarefællesskaber, kommunale klimaambassadørordninger, og senest initiativer som Den Grønne Studenterbevægelse og Extinction Rebellion.
} 
for forskellige former for bæredygtige fællesskaber, hvor et fokus på kollektive dynamikker vurderes at have en vigtig indflydelse på ændringen af borgeres adfærd (Gausset 2019; Ecolise 2019). De bæredygtige fællesskaber præsenteres som et vigtigt supplement til de individfokuserede initiativer såsom økonomiske subsidier og teknologiske løsninger, der hidtil ikke har medført den ønskede effekt i ændringen af borgernes adfærd (Dobson 2007; Gausset og Tjørring 2016).

Denne artikel omhandler økosamfund ${ }^{2}$, som er en form for et bæredygtigt fællesskab, hvor kollektiv livstil praktiseres i et vist omfang. På baggrund af et etnografisk feltarbejde undersøger artiklen den aktivistiske indsats på forskellige skalaer: lokalt niveau i udvalgte danske økosamfund, nationalt niveau i Landsforeningen for Økosamfund (LØS) og internationalt niveau i Global Ecovillage Network (GEN). Som Thomas Hylland Eriksen (2016) beskriver: "The world, or an activity, or an idea, [...] changes when you move it up and down the scales" (Eriksen 2016, 482). På samme måde viser denne artikel, hvordan forskellige former for aktivisme i økosamfund og økosamfundsbevægelsen ændrer sig afhængigt af, hvilken skala denne aktivisme kommer til udtryk på. Aktivisme defineres her som handlinger, der udføres med det formål at skabe politisk og social forandring. Med brug af begreberne praktivisme, der fokuserer på individuel livsstil, mikroaktivisme der fokuserer på kollektiv livsstil i økosamfund og makroaktivisme, der fokuserer på økosamfundslivsstil på et samfundsmæssigt plan, argumenterer artiklen, hvordan aktivismen foregår på flere skalaer blandt økosamfundsbeboere og netværkere.

Artiklen indledes med en baggrundsbeskrivelse af økosamfund og økosamfundsbevægelsen. Hernæst følger en gennemgang af den etnografiske data, der er indsamlet i tre danske økosamfund og i LØS- og GEN-netværk. Med afsæt i samfundsvidenskabelig litteratur om miljø- og klimaaktivisme, både i sociale bevægelser og gennem individuelt engagement, foreslår artiklen, at økosamfund som livsstil repræsenterer en form for kollektiv mikroaktivisme. Den antropologiske analyse tager udgangspunkt i en empirisk vignet, der viser de forskellige aktivismeformer i økosamfund og økosamfundsbevægelsen, repræsenteret af beboere og netværkere. Ligeledes beskrives det $\mathrm{i}$ analysen, hvordan økosamfundsbeboeres bæredygtige livsstil praktiseres for at skabe et velfungerende fællesskab. Dermed argumenteres der for, hvordan den (mikroaktivistiske) forandringsskabende kollektive handling, som praktiseres i økosamfundene repræsenteres af (de makroaktivistiske) netværkere i større skala gennem deres arbejde for en ændring udad i samfundet. Det vises dermed, hvordan de forskellige skalaer har en gensidig betydning.

\footnotetext{
2 ‘Økosamfund’ er én kategorisering ud af mange mulige. Således bruges også betegnelser som ‘økolandsby’ ('ecovillage' i internationale sammenhænge), 'intentional community', ‘økologisk bofællesskab' foruden de stedsspecifikke navne for de enkelte fælleskaber, når denne boligform og livsstil omtales. For enkeltheds skyld, dækker 'økosamfund' for tiltag i både danske og internationale sammenhænge i denne artikel.
} 


\section{Økosamfund i Danmark}

Økosamfund er en boligform og en livsstil, der dækker over en bred vifte af måder at organisere hjem og hverdagsliv på. For de fleste danske økosamfunds tilfælde gælder det, at beboerne bor i private boliger bygget ud fra forskellige bæredygtige principper i et afgrænset bofællesskab. Bofællesskaberne fungerer som foreninger med værdigrundlag og vedtægter, der vægter temaer såsom natur, miljø, naboskab, deleøkonomi og praktisk samarbejde højt, om end værdier og kendetegn varierer fra økosamfund til økosamfund (Litfin 2014; Lockyer og Veteto 2013; Marckmann 2009; Marckmann et al. 2012; Miller 2018; Reinholdt 1997). Økosamfund er forskellige i størrelse med 80 beboere i nogle og op til 300 i andre. Ligeledes varierer designet, der nogle steder er karakteriseret ved strømlinede rækkehuse og andre steder unikke og individuelt byggede halmhuse. Som fællesnævner gælder det, at økosamfundene har en fælles bygning som centrum for bofællesskabets aktiviteter, der blandt andet består af fællesspisninger, møder, sociale aktiviteter, affaldsrum og deleordninger. Blandt mere omtalte danske økosamfund kan nævnes Dyssekilde ved Torup på Nordsjælland, Munksøgaard i Trekroner ved Roskilde og Friland på Djursland. Der har i de seneste år været en stærkt stigende interesse for eksisterende økosamfund og andre former for bæredygtige bofællesskaber og initiativtagen til nye projekter (Udlændinge-, Integrations- og Boligministeriet 2016; LØS 2016). Ydermere er der kommet projekter, der arbejder med en forberedt initiering af økosamfund med det formål at tiltale en større gruppe af potentielle beboere, der finder en etableringsfase på eget initiativ for omfattende (Bærebo 2019; EcoVillage 2019). Der eksisterer omkring 50 økosamfund rundt i Danmark, mens det estimeres, at andre 30 er i projektfasen. Dermed er Danmark det land i verden, der har det højeste antal af økosamfund pr. indbygger (LØS 2018). Tidligere studier af økosamfund har diskuteret, hvorvidt denne boform medfører en mere bæredygtig og miljøvenlig livsstil sammenlignet individuelle boligformer, eksempelvis i forhold til biltrafik, da økosamfund ofte ligger i landdistrikter med begrænset mulighed for kollektiv trafik. Dog fremhæves den sociale organisation i økosamfund som medvirkende faktor til en bæredygtig livsstil, da der bliver pointeret, at det kollektive aspekt styrker beboeres motivation for at opretholde principperne for en bæredygtig økosamfundslivsstil (Marckmann et al. 2012, 428).

\section{Økosamfundsbevægelsen}

Arbejdet med at udbrede budskabet om de bæredygtige potentialer, som økosamfund viser, udføres af Global Ecovillage Network $(\mathrm{GEN})^{3}$ på et globalt plan og Landsforeningen for Økosamfund (LØS) på et dansk, nationalt plan. De fleste danske økosamfund er re-

\footnotetext{
${ }^{3}$ GEN er inddelt i regionale sammenslutninger, og det er derfor den europæiske samling, 'GEN-Europe', der refereres til i denne artikel.
} 
præsenteret af LØS, der udgøres af en bestyrelse og et sekretariat, hvoraf en del medlemmer og ansatte selv bor i et dansk økosamfund. Officielt hedder det, at LØS, samler “[...] de danske økosamfund, giver mulighed for erfaringsudveksling og arbejder politisk for at fremme økosamfundene i Danmark og inspirere det øvrige samfund til et mere bæredygtigt liv" (LØS 2019). Danske deltagere i GEN-netværk og -konferencer er både økosamfundsbeboere, LØS-medlemmer og andre, der har interesse i økosamfundsbevægelsen, uden nødvendigvis at være tilknyttet et økosamfund selv. GEN præsenterer sin vision som værende en forestilling om "[...] a world of empowered citizens and communities, designing and implementing pathways to a regenerative future, while building bridges of hope and international solidarity" (GEN 2019a). Både LØS og GEN arbejder således for en ændring af samfundet og har en intention om at inspirere til et bæredygtigt liv ved at efterleve principper fra økosamfund (GEN 2019b) ${ }^{4}$. Der er altså engagement på forskellige skalaer inden for økosamfundsområdet i Danmark: lokalt i og omkring det enkelte økosamfund, i LØS og i GEN 5 .

Siden LØS og GEN's opstart i midten af 1990'erne, har der været et stigende fokus på at styrke disse netværk. Indtil da var økosamfund ikke udpræget organiseret med hinanden, hverken nationalt eller globalt. Trods det faktum at økosamfundene blandt meget andet delte miljøværdier, var fokus på at opbygge fællesskab frem for netværk (Lovell 2012). Mange økosamfundsbeboere prioriterer imidlertid fortsat at opbygge fællesskab, og som Marckmann (2009) også pointerer er "Økosamfundsbevcegelsen [...] ikke nødvendigvis lig med økosamfundenes beboere" (Marckmann 2009, 71). Denne artikel viser imidlertid, hvordan økosamfundsbevægelsens arbejde er forudsat af eksistensen af økosamfund. Således argumenteres det, at beboere, gennem deres engagement for at skabe et velfungerende fællesskab har en aktivistisk funktion, om end på en anden skala end den, netværkerne repræsenterer.

Netværkeres mangeårige arbejde for at styrke økosamfund og inspirere flere borgere til at leve efter økosamfundsprincipper, har i de seneste år resulteret i en 'signifikant transformation' af forholdet mellem økosamfundsbevægelsen og det omgivende samfund - også italesat som mainstream society (Dawson 2013, 226). Dawson beskriver, hvordan borgere i det 'globale nord' i stigende grad praktiserer mange af de bæredygtige principper, økosamfund er karakteriseret ved - for eksempel brugen af vedvarende energi, bygning af energi-effektive boliger og gennemgribende affaldssystemer - som økosamfund har vist vejen for og på visse punkter været med til at udvikle (Dawson 2013, 223). Flere beboere i danske økosamfund italesætter, hvordan det omgivende samfund kan synes

\footnotetext{
${ }^{4}$ Denne artikel tager udgangspunkt i et miljø- og klimafokus, men da økosamfundsprincipperne, som de er defineret af GEN, ikke kun omhandler miljø- og klimaspørgsmål, men også er fokuseret sociale, kulturelle og økonomiske visioner, vil disse aspekter også være inkluderet, når principper, visioner og idealer for økosamfund og økosamfundsbevægelsen adresseres.

${ }^{5}$ Denne skala-inddeling er udtryk for et udpluk af de netværk, beboere i danske økosamfund tager del i. Således er nogle økosamfundsbeboere mere aktive i f.eks. Landsforeningen Økologisk Byggeri (LØB) eller sammenslutningen af grønne danske organisationer og fællesskaber, 'Det Fælles Bedste'. Fokus på LØS og GEN i denne artikel er valgt ud fra en vurdering af, hvor dynamikken mellem beboere og netværkere er fremkommet særligt tydelig i den indsamlede data.
} 
mere effektivt og på nogle punkter ligefrem overhaler deres økosamfund indenom i forhold til eksempelvis byggemetoder, energiløsninger eller økologisk landbrug. Mange beboere har dog alligevel en overbevisning om, at deres måde at indrette og strukturere deres hverdagsliv på - i tæt samarbejde og praktisk fællesskab med deres naboer - gør det nemmere for dem at leve bæredygtigt både socialt, økonomisk og miljømæssigt sammenlignet hvis de boede i konventionelle individbaserede boformer (Alphafilm 2018; Jensen et al. 2019).

\section{Etnografisk dataindsamling}

Nærværende artikel baserer sin analyse på data, der er indsamlet gennem etnografisk feltarbejde i perioder hen over årene 2017-2019. Feltarbejdet har hovedsageligt koncentreret sig til ophold og tilbagevendende besøg i tre danske økosamfund i forskellige dele af landet, hvor jeg har deltaget i hverdagslivet og skabt relationer til beboerne. Med base i private hjem og gæstehuse har jeg været del af hverdagen ved at deltage i praktiske arbejdsopgaver som havearbejde, vedligeholdelse af fællesområder og madlavning til fællesspisninger. Jeg har observeret beslutningsprocesser ved fællesmøder og generalforsamlinger, foretaget semi-strukturerede interviews samt ført såkaldt uformelle samtaler i en lang række af spontane sociale situationer med børn og voksne rundt om disse hverdagsaktiviteter. Jeg har således både boet $\mathrm{i}$ og studeret hverdagen for beboere $\mathrm{i}$ tre danske økosamfund, hvilket har givet en særlig indsigt i, hvordan bæredygtigheds- og fællesskabsværdier forstås og praktiseres. Samtidig har jeg undersøgt, hvordan beboere placerer sig selv og deres økosamfund, og opfatter deres roller, i den bredere økosamfundsbevægelse.

Foruden feltarbejdet lokalt i økosamfundene, har jeg blandt andet gennem deltagelse $\mathrm{i}$ et højskoleophold arrangeret af LØS og studieture til et udsnit af andre danske økosamfund med medlemmer af LØS fået en indsigt i den danske økosamfundsbevægelse på et netværksmæssigt plan. Endelig har jeg tre år i træk deltaget i den årlige Global Ecovillage Network konference i forskellige økolandsbyer i henholdsvis Sverige, Estland og Italien, hvor jeg har observeret og deltaget i netværk for danske og internationale medlemmer af GEN. Feltarbejdet har resulteret i et omfattende notemateriale foruden transskriberede interviews og opfølgende korrespondancer med informanter. Navne på de økosamfund, jeg har boet i og besøgt, og informanter fra både økosamfund og LØS- og GENnetværk er anonymiseret i denne artikel.

Rollen som feltarbejder har altså både været karakteriseret ved en position som aktiv deltagende og passiv observatør i såvel økosamfundenes hverdagsliv og LØS’ og GEN's netværk. Positionen som medvirkende aktør i felten er essentiel for at skabe en forståelse for de dynamikker og praksisser, der udspiller sig både lokalt og globalt i økosamfund og økosamfundsbevægelsen. Deraf følger også, at planlægningen af de forskellige feltarbejder i nærværende projekt er sket $\mathrm{i}$ en løbende proces, $\mathrm{i}$ takt med at indsigten i felten og forståelsen for, hvor og hvordan det var betydningsfuldt at indsamle empiri, 
udviklede sig. Som Bruno Latour argumenterer, er "Valget [...] altså klart: Enten følger vi samfundsforskerne og begynder vores rejse med umiddelbart at bestemme os for, hvilken gruppe og hvilket analytisk niveau, vi vil beskæftige os med; eller vi følger aktørernes egne veje og begynder rejsen i sporene af de handlinger, der danner og opløser grupper" (Latour 2008, 51). På samme måde begyndte jeg at undersøge beboere og netværkeres aktivistiske praksis mere indgående, $\mathrm{i}$ takt med at vigtigheden af denne empiriske indsigt blev tydelig undervejs i feltarbejdsforløbet.

Klima- og miljøbevægelser fra et samfundsvidenskabeligt perspektiv

Siden opstarten af de første miljøbevægelser i 1970'erne har samfundsvidenskaberne beskæftiget sig med indsatser i bevægelser og organisationer og analyseret disse ud fra en aktivistisk vinkel. Mange studier af miljø- og klimaaktivisme har fokuseret på grupper og bevægelser, der er synlige gennem demonstrationer, politiske protester og lobbyarbejde, og som på forskellig vis forsøger at påvirke lovgivning, politikere og multinationale virksomheder (Benedikter et al. 2016; Della Porta et al. 2015; Doherty 2002; Jamison et al. 1990; Kamieniecki 1993; Krøijer 2019; McKay 1998; Scheidel et al. 2018; Wapner 1995). Kendetegnende for disse studier er deres udgangspunkt i et makro-perspektiv med fokus på (ofte, om end ikke udelukkende) transnationale organisationer og initiativer som eksempelvis Greenpeace og anti-kulmine-grupper. En anden vinkel på engagement $\mathrm{i}$ klima- og miljøspørgsmål ses i et stigende fokus på betydningen af hverdagspraktiske tiltag. Ifølge Haenfler et al. (2012) har der i samfundsvidenskabelig litteratur været en skarp distinktion mellem de sociale bevcegelser, der er defineret som "[...] organized, change-oriented collective action aimed at the state or other authority structures [...]" og livsstil som er "[...] more diffuse, internally focused, style-oriented groupings driven by consumption and popular culture" (Haenfler et al. 2012, 1). Haenfler et al. argumenterer, at denne adskillelse har skabt en videnskabelig blind vinkel for skæringspunktet mellem privat handling og deltagelse i en bevægelse. Således plæderer de for et øget fokus på livsstilsbevægelser (life style movements), der “[...] consciously and actively promote a lifestyle, or way of life, as their primary means to foster social change (Haenfler et al. 2012 , 2). Som eksempler på livsstilsbevægelser med klima- og miljøfokus nævnes 'slow food', vegetarisme og 'green living' (Haenfler et al. 2012, 5).

Et andet samfundsvidenskabeligt argument om at rette fokus mod det klima- og miljøengagement, borgere repræsenterer uden at organisere sig i konkrete sociale, politiske eller aktivistiske bevægelser finder vi hos Hoff et al. (2019), der introducerer begrebet 'praktivisme'. Ifølge Hoff et al. er praktivisme en form for aktivisme, der illustrerer den nylige opblomstring af miljø- og klimainitiativer, hvor borgere vender deres indsats og fokus indad frem for at kæmpe for en ændring udad i samfundet: "Practivism is here not understood as the practical methods of doing activism [...] but is rather defined as a new form of activism that is based on changing one's own practices rather than changing those of others” (Hoff et al. 2019, 6). I Hoff et al.'s optik er praktivisme således borgeres forsøg 
på selv at skabe de nødvendige adfærdsændringer, som det internationale samfund og nationale regeringer - og dermed indirekte også de aktivister, der har forsøgt at påvirke disse - ikke er lykkedes tilstrækkeligt med. Både Haenfler et al. og Hoff et al. fokuserer således på borgere, hvis hverdagspraksis er med til at skabe en social forandring (se også Henrik Bangs teori om hverdagsmagere (everyday makers) for et andet eksempel på politisk deltagelse, der ikke er organiseret i større bevægelser (Bang 2003)). Nærværende artikel repræsenterer både et aktivistisk fokus gennem netværkeres ønske om at forandre samfundet gennem engagement i økosamfundsbevægelsen og et praktivistisk fokus $\mathrm{i}$ form af beboeres individuelle bæredygtige livsstil. Samtidigt gør artiklen brug af begrebet mikroaktivisme, som et begreb, der placerer sig imellem beboeres praktivistiske engagement $i$ deres personlige liv og netværkeres aktivistiske engagement i en national og global arena. Mikroaktivismen står således for det kollektive engagement, økosamfundsbeboere viser i deres fællesskab, hvor den bæredygtige hverdagspraksis ikke først og fremmest sker for de individuelle beboeres skyld, men for at sikre selve eksistensen af økosamfundet. Det er således i mikroskala - i mikro(øko)samfundet - at en politisk og social forandring ønskes. Den forandringsskabende kollektive handling, som praktiseres i økosamfundene repræsenteres dernæst af netværkere i større skala gennem deres arbejde for en ændring udad i samfundet, og mikroaktivismen udgør på den måde fundamentet for det makroaktivistiske arbejde.

\section{Beboere og netværkere}

"Jeg tror, man kan lave en distinktion mellem beboere og netvaerkere ${ }^{6}$. Netværkere er de økosamfundsbeboere, som er interesserede i at rejse ud og sprede det gode budskab og formidle om denne måde at bo og leve på, mens beboere er dem, der ønsker en mere tilbagetrukket tilværelse, hvor energien lægges i fællesskabet derhjemme i økosamfundet” (GEN 2017).

Sådan svarede præsidenten for GEN International, da jeg på netværkets årlige europæiske konference i Sverige i sommeren 2017 spurgte ham, hvordan beboere i økosamfund oplevede at tage del i en større bevægelse.

Da jeg kort tid efter konferencen påbegyndte feltarbejde i et dansk økosamfund, præsenterede jeg den foreslåede distinktion mellem beboere og netværkere for en kvindelig informant, hvortil hun konstaterede: "Vi er nok mest beboere her hos os. Jeg er ikke sikker på, at alle i det her økosamfund ved særligt meget om, hvad eksempelvis LØS arbejder for". Selv var denne informant i en periode ansat i LØS som medarbejder, og havde derigennem kendskab til organisationen og dens samarbejde med GEN og andre større netværkssammenslutninger. På trods af at have haft en repræsentant i LØS, havde beboerne i det pågældende økosamfund altså ikke en selvopfattelse af at være netværkere

\footnotetext{
6 'Settlers' og 'networkers', min oversættelse
} 
i GEN-præsidentens forståelse af begrebet. Denne artikel argumenterer for, at selvom beboere som den omtalte kvinde ikke ser sig selv som netværkere, praktiserer de en aktivistisk indsats i mikroskala, som fungerer som det gode eksempel, der videreføres af netværkere på en makroaktivistisk skala. I følgende empiriske beskrivelse, der udspiller sig i en weekend i et dansk økosamfund i august 2017, vises forskellige eksempler på engagement internt i økosamfundet og eksternt i både LØS’ bestyrelse og partipolitisk arbejde.

Sammenlignet med hverdagene er der her $i$ weekenden mere liv og aktivitet i fallesområderne. 'Oppe’ på gården, som fungerer som folleshus, fødevarelager, affaldssortering, byttebiks og en nyligt indviet gildesal på det gamle høloft, er en gruppe af voksne i gang med at rydde op. LØS skal holde bestyrelsesmøde her i økosamfundet denne weekend, da deres møder ofte holdes rundt $i$ de danske økosamfund med den hensigt at loere beboerne og foellesskaberne at kende. Jeg opfanger ikke, om oprydningen og den praktiske indsats, som jeg ikke har oplevet $i$ samme grad $i$ de seneste fire uger, hvor jeg har boet $i$ økosamfundet, sker fordi LØS kommer på besøg. Det kan også vare fordi, der i dag er den månedlige rundvisning for interesserede udefrakommende, eller blot fordi sommerferietiden er ovre, og der er motivation for at få klaret nogle af alle de praktiske opgaver, der skal til for at opretholde et økosamfund som dette.

Inde i gårdens køkken stiller en kvindelig beboer an til frokost. "Det plejer vi da ikke at spise falles", kommenterer jeg. "No", svarer hun, "men jeg fik lige lyst til at lave det og give en hjolpende hånd til alle dem, der rydder op i laden, bygger hønsehus og så videre”. Jeg scetter mig ved den håndfuld af beboere, der spiser med til frokost og bemorker, hvordan to mandlige beboere - der begge har job inden for IT og til dagligt går kladt i skjorte, men i dag har beskidte overalls på - taler om det hønsehus, de er i faerd med at bygge, og som har stået halvfoerdigt "alt for longe". Vi sidder ved borde-bonkescettene i den ene ende af gårdspladsen og kigger over mod den anden ende, hvor LØS-bestyrelsen er ankommet og har sat sig til rette. Flere af beboerne tager ikke scerlig notits af bestyrelsens tilstedevarelse, og ved ikke helt, hvorfor de er der, da det er nogle enkelte kontaktpersoner fra økosamfundet, der har stået for arrangementet.

Senere på dagen samles den gruppe af interesserede, der skal vises rundt $i$ økosamfundet for at få et kendskab til, hvordan den boredygtige livsstil er bygget op gennem byggeteknikker, foelles madordning, deleøkonomi, spildevandspileanloeg, hobbylandbrug, mødestruktur og ikke mindst tilgangen til fallesskab. Nogle har et ønske om at flytte ind, mens andre blot er nysgerrige for at vide, hvad sådan et liv i et økosamfund er for noget. Flere udtrykker overraskelse over, hvordan samfundet på den ene side er 
gennemført boredygtigt ift. energi, natur, mad, forbrug og ikke mindst det toette naboskab, samtidig med at beboernes hverdag minder om livet i et konventionelt boligkvarter, som de parcelhusveje, samfundet ligger lige op ad.

Om aftenen hjoelper jeg med forberedelserne til fallesspisningen. Der er forvirring ud over det scedvanlige, og dagens madlavning er mere kompliceret end det daglige forventelige kaos for at lave middag for samfundets omtrent 40 daglige medspisere, fordi LØS-gruppen skal spise med, og der har derfor vaeret tvivl om ansvarsfordelingen af maden. Derudover sidder dagens ansvarlige 'kok' midt $i$ et møde med den lokale afdeling af partiet Alternativet, og denne gruppe af medlemmer spiser også med. Det ender med, at medlemmer af LØS ogjeg tager os af en stor del af madlavningen. På trods af kaosset, ender vi med at få mad på bordet til den ekstraordincert store forsamling. På gårdspladsen, hvor der må ekstra borde-bcenkescet til for at have plads til alle, bemorker jeg, hvordan der foregår opdelte samtaler mellem beboere $i$ den ene halvdel og gaster fra LØS og Alternativet $i$ den anden.

Noeste dag deltager jeg $i$ det annoncerede møde med et folketingsmedlem fra Alternativet på den lokale friskole. Jeg forestiller mig på forhånd, at beboere vil deltage i mødet, da adskillige har udtrykt voerdier og holdninger, der stemmer overens med dette politiske parti. Da jeg ankommer, er det dog kun økosamfundets eget partimedlem, der er tilstede.

Hjemme igen i økosamfundet hjoelper jeg en mandlig beboer med at forberede søndagens foellesspisning. Han laver pizza, og fär hjoelp af sin yngste søn på fem år. Jeg går ud i køkkenhaven og plukker majs, der også skal indgå i menuen. Jeg har fået besked på, at det er vigtigt, at alle majsbladene bliver samlet op og smidt direkte $i$ komposten, da der er mange drcebersnegle $i$ haven, som tiltrcekkes af haveaffaldet. Mens jeg piller blade af og skyller majsene, fortoeller jeg den mandlige beboer om Alternativets møde, og spørger ind til, om han vidste, at det foregik her til eftermiddag. Jeg henviser også til den seddel, der hoenger $i$ spisestuen $i$ rummet ved siden af os, der reklamerer for arrangementet. "Det interesserer mig ikke så meget med det politiske” kommenterer han, mens han arbejder videre med at lave aftensmaden til de medbeboere, der deltager i foellesspisningen i dag. 


\section{Beboeres engagement i økosamfund}

Som det fremgår af denne empiriske beskrivelse, er der forskellige måder, hvorpå beboere og netværkere engagerer sig i økosamfund, økosamfundsbevægelsen og partipolitisk arbejde.

Beboerne lægger deres engagement i deres økosamfund. De bruger deres fritid i denne weekend på at ordne praktiske opgaver eller stå klar med frokost til resten af fællesskabet. Hverdagen bruger de, foruden at passe deres job uden for økosamfundet, i høj grad sammen med deres (eventuelle) børn og naboer i økosamfundet. Her passer de deres praktiske ansvarsområder såsom at luge køkkenhaven, rydde op i affaldsrummet eller passe økosamfundets fælles dyr. De fleste beboere har brugt en årrække på at bygge deres egne huse efter bæredygtige principper, som eksempelvis at bruge nedbrydelige eller genbrugte materialer, etablere komposttoilet og installere solfangere til opvarmning af vand. Mange selvbyggere udtrykker, hvordan det har været en drøm for dem at bygge deres eget hus og sikre bæredygtige rammer for deres hverdagsliv. Kombineret med ønsket om at have tætte relationer til deres naboer, har fællesskabet i et økosamfund derfor været en ideel ramme at flytte ind i. Valget om at bo i økosamfund har altså handlet mere om en vilje til at have en bæredygtig hverdagspraksis sammen med og ved hjælp af et fællesskab, end om at markere et personligt miljø-og klimamæssigt standpunkt. I forlængelse heraf blev det til rundvisningen den pågældende weekend såvel som til adskillige andre rundvisninger, jeg oplevede under mit feltarbejde, aldrig italesat, at borgere uden for økosamfund burde tilegne sig de bæredygtige strukturer, økosamfundet er bygget op om. Derimod blev der fortalt og forklaret ud fra det perspektiv, at "sådan har vi valgt at gøre det hos os". På samme måde forklarede en beboer under et skoletjenestebesøg, på et senere tidspunkt i dette økosamfund: "Vi tænker faktisk ikke så meget på $\mathrm{CO}_{2}$. Vores hverdag er jo allerede bygget op, og økosamfundet struktureret på sådan en måde, at vi har en $\mathrm{CO}_{2}$-venlig adfærd, selvom vi ikke går og er bevidste omkring det hele tiden”. Forklaringen var et svar på en 8 . klasses elevs kommentar om, at han ikke kunne forestille sig at bo, som de gør i økosamfundet, fordi han ikke ville kunne holde ud at skulle tænke så meget på $\mathrm{CO}_{2}$ hele tiden. Informantens svar viser, ligesom fortællingerne til de besøgende ved weekendrundvisningen, at beboernes bæredygtige praksis på mange måder er indlejret, og at de ikke oplever den som værende ekstraordinær. Tværtimod udtrykker de ofte, at de godt kunne være mere ambitiøse, når det kommer til $\mathrm{CO}_{2}$-aftryk.

Forskellen mellem at være beboer og netværker den omtalte weekend, bliver særligt tydelig i tilfældet, hvor en mandlig beboer bogstaveligt talt springer mellem på den ene side sit møde i den lokale Alternativet partigruppe ude $i$ haven (hvor et besøg af en folketingspolitiker i lokalområdet den efterfølgende dag skal arrangeres) og madlavningen til fællesspisning inde i køkkenet, som denne dag er hans praktiske ansvar i økosamfundet. Til arrangementet med folketingspolitikeren den efterfølgende eftermiddag, bliver der debatteret, hvordan den bæredygtige omstilling af samfundet kan se ud, og hvordan han som politiker forsøger at skabe politisk opmærksomhed om emnet. Hjemme i økosamfundet oplever jeg beboer-tilgangen som kontrast til den politiske debat: for at et 
økosamfund kan fungere (og visionen om bæredygtig livsstil kan blive en realitet) skal dræbersnegle holdes væk fra køkkenhaven, og aftensmaden til fællesspisningen skal stå klar til tiden, uagtet at der er en folketingspolitiker på besøg i lokalområdet. At pågældende beboer går mere op i sine pligter og interesser hjemme i økosamfundet illustrerer i denne artikels optik, hvordan beboere ikke oplever deres økosamfund som en politisk arena, hvor aktiviteter og fællesarbejde udføres ud fra en politisk vision. Derimod udføres de ud fra nødvendigheden af at skabe et levedygtigt fællesskab i økosamfundet.

\section{Et bofællesskab og en bevægelse}

Der er altså en forskel på beboere og netværkeres engagement $i$ den omtalte weekend $i$ et dansk økosamfund. Med Anna Tsings (2005) ord kan det argumenteres, at der opstår friktion mellem den lokale og globale (i den omtalte weekends tilfælde den nationale) kontekst (Tsing 2005). Friktionen sker ikke kun i det direkte møde beboere og netværkere imellem, som weekenden i det pågældende økosamfund eksemplificerer. Generelt hersker der i økosamfundsbevægelsen en diskrepans imellem netværkernes ambitioner præsenteret på konferencer og gennem politisk lobbyarbejde på vegne af økosamfund, og den indstilling, beboerne 'derhjemme' har. Denne forskel ses særligt i den måde, visioner kommunikeres på. På GEN-konferencer diskuteres der eksempelvis, hvordan budskabet om økosamfunds potentialer kan få politisk slagkraft og en større outreach kan skabes. Som en netværker udtrykte det til en workshop om Ecological Lobbyism and Activism på GEN-konferencen i sommeren 2019: "Hvordan kan vi få samme indflydelse som forandringsmagere som Greta Thunberg? Hvordan kan vi være tydeligere? Vores budskab bliver hørt politisk, men ikke nok". Heroverfor er økosamfundsbeboere mere interesserede $i$ at skabe indsatser derhjemme, hvor skoletjenestebesøg, rundvisninger og i nogle økosamfunds tilfælde høstmarkeder eller festivaler arrangeres som en form for lokal outreach. Desuden er det ofte en mindre gruppe af beboere, der står for disse arrangementer, mens resten af beboergruppen tager del i andre af økosamfundets arbejdsområder. Friktionen sker dog ikke som et udtryk for en ligegyldighed eller bevidst distanceren beboere og netværkere imellem. Derimod er den et eksempel på, hvordan aktørerne angriber det at være engagerede på mikroniveau i økosamfundet eller makroniveau i økosamfundsnetværk. Mens beboerne i samarbejde bruger deres tid i den omtalte weekend på at få nogle praktiske opgaver i fællesskabet fra hånden, bruger netværkerne fra LØS og Alternativet en stor del af deres fritid på deres respektive bestyrelsesarbejde.

\section{Mikro- og makroaktivisme}

Netværkeres aktivistiske arbejde på makroniveau er afgjort af, at der eksisterer økosamfund, som kan eksemplificere deres politiske budskaber gennem beboeres mikroaktivisti- 
ske engagement. Netværkerne engagerer sig udad, beboerne indad. Beboernes engagement lægger sig dermed op ad begrebet praktivisme, idet, at de ønsker at ændre egen praksis frem for at arbejde for at andre skal ændre deres. Som det er argumenteret, ligger beboeres prioritet ikke $\mathrm{i}$ at fortælle omverdenen (hverken den lokale omverden i form af rundvisning og skoletjeneste, eller den nationale og internationale gennem deltagelse $\mathrm{i}$ LØS og GEN), hvordan deres økosamfundsmodel er en ideel livsstil i forhold til miljømæssig, økonomisk og social bæredygtighed. På samme måde ligger det beboere på sinde, ikke at blande sig i, i hvilken grad, deres medbeboere praktiserer en bæredygtig livsstil i deres private hjem i økosamfundet. Alligevel er der forskel på den form for praktivisme, der ses i andre kollektive bevægelser såsom fødevarefællesskaber, hvor medlemmernes bæredygtige (individuelle) praksis muliggøres ved hjælp af et fællesskabsinitiativ (Hoff og Islar 2019, 26) og den, vi ser praktiseret i bofællesskaber som økosamfund. Økosamfundsbeboeres praktivistiske livsstil kommer til udtryk i deres privatliv; i deres private bolig og i de andre individuelle sfærer, de bevæger sig i i hverdagslivet såsom deres arbejdsplads, børnenes skole, og samvær med familie og bekendte uden for økosamfundet (Hansen 2019). Den hverdagspraksis, der foregår i fællesskabet, er til gengæld mikroaktivistisk: i økosamfundets fysiske og sociale strukturer (formuleret som økosamfundsprincipper i visioner og vedtægter), er der klare retningslinjer for blandt andet fællesspisninger, fødevareindkøb, energiforsyning, affaldssortering og beslutningsprocesser. Økosamfundet fungerer altså - som betegnelsen indikerer - som et afgrænset og gennemdesignet mikrosamfund, og den bæredygtige praksis er ikke først og fremmest et udtryk for beboernes personlige livsstilsvalg, men derimod en måde at opretholde fællesskabet $\mathrm{i}$ økosamfundet på. Den bæredygtig livsstil er altså determineret af den kollektive praksis. Økosamfundet er derfor ikke kun sat i verden for at beboerne enkeltvis kan være mere bæredygtige, sammenlignet med hvis de levede i andre konventionelle boformer; beboernes engagement $\mathrm{i} ø$ kosamfundet sker for at opretholde selve økosamfundet og gøre dette levedygtigt. Som det er beskrevet, udtrykker beboere, at de ikke tænker deres relativt lave $\mathrm{CO}_{2}$-forbrug eller bæredygtige livsstil som imponerende. Tværtimod påpeger de ofte, hvordan de kunne 'gøre mere', og direkte adspurgt, betragter de ikke deres engagement som aktivistisk på samme måde som de mener, netværkernes engagement er. Derimod opfatter de sig selv som værende 'bare beboere'. I denne artikels optik er dét, bare at være beboer, dog netop lig med et aktivistisk engagement, om end på et mikroniveau, da beboeres daglige indsats for at gøre deres fællesskab velfungerende viser, at de ønsker en social forandring ske internt i deres eget mikrosamfund. Til trods for, at alle økosamfundsbeboere ikke er aktive i økosamfundsbevœegelsen argumenterer nærværende artikel således for, at beboere er med i bevægelsen per se gennem deres mikroaktivistiske engagement. Ifølge Hoff et al., er forskellen mellem den 'klassiske' aktivisme og den nye praktivisme da heller ikke ensbetydende med, at der er et klart skel imellem de to tilgange; tværtimod eksisterer der "[...] a continuum between the two ideal types, and many people are involved in both activism and practivism" (Hoff et al. 2019, 7). Denne artikel har med begrebet mikroaktivisme illustreret, hvordan der med udgangspunkt i økosamfundslivs- 
stilen eksisterer endnu en skala i dette kontinuum - en form for aktivisme, der er altafgørende for selve eksistensen af økosamfund og dermed den livsstil, boformen repræsenterer. Ud fra nærværende analyse kan det derfor argumenteres, at en balance mellem praktivisme, mikroaktivisme og makroaktivisme er væsentlig for på den ene side at skabe levedygtige fællesskaber lokalt og på den anden side at muliggøre den netværksindsats, der forsøger at udbrede budskabet om økosamfundslivsstilen.

\section{Konklusion}

Denne artikel har givet et indblik i, hvordan feltet af økosamfund og diverse initiativer, bestyrelser og netværk inden for økosamfundsbevægelsen bliver deltaget i på forskellig vis og med forskellige indstillinger. Med udgangspunkt $i$ en empirisk case fra et dansk økosamfund blev det tydeliggjort, hvordan der er forskel på beboere og netværkere. Beboerne lægger fokus indad i deres økosamfund og engagerer sig mikroaktivistisk med fokus på at ændre mikro-politik i deres mikro-samfund, mens netværkere også fokuserer udad og deltager i diverse møder, events og konferencer for at tale økosamfundenes sag - en mere traditionel form for aktivisme med fokus på at ændre politik og samfund på nationalt og globalt niveau.

På trods af disse forskelle, deler beboere og netværkere værdier og visioner for en bæredygtig livstil. De kæmper altså for samme sag, men kæmper den i forskellige skalaer til forskellige tider. Nogle fokuserer på mikroniveau og engagerer sig med deres medbeboere og arbejder for at forbedre vedtægter og hverdagsliv i deres økosamfund; andre fokuserer på det nationale eller internationale niveau og laver politisk lobby-arbejde for at påvirke lovgivning og miljø- og klimapolitik. Der findes ligeledes engagement på mesoniveau, hvor lokalsamfund inviteres ind i økosamfundene eller samarbejder med skoler og kommuner etableres. På tværs af de forskellige skalaer ser man dog de samme grundlæggende værdier bag de forskellige former for aktivisme, som udfolder sig. Der finder ligeledes en gensidig afhængighed sted, da netværkere har brug for en velfungerende model på mikroniveau, som de kan forsøge at skalere op, mens beboere har brug for netværkere som varetager deres interesser og bekæmper administrative og politiske barrierer, der kan udfordre eksempelvis etablering af virksomheder i økosamfundet eller udbygninger med flere boliger eller fælleshuse. Beboere og netværkere lever imidlertid også en praktivistisk livsstil, som finder sted i den del af deres hverdag, hvor de ikke er engagerede i fællesskabet i deres økosamfund eller i deres arbejde i økosamfundsbevægelsen. Således sker den sociale forandring fortolket ud fra økosamfundsprincipper i en gensidig proces mellem et praktivistisk, mikroaktivistisk og makroaktivistik engagement. 
Litteratur

AlphaFilm (2018). Cirkulær økonomi. Forandringer nedefra. Vimeo. Tilgængelig på: https://vimeo.com/288735738. [Tilgået d. 10. oktober 2019].

Bang, H. (2003). A New Ruler Makes a New Citizen: Cultural Governance and Everyday Making. I: Bang, H.P., red., Governance as Social and Political Communication. Manchester: Manchester University Press.

Benedikter, R., Kühne, K., Benedikter, A., Atzeni, G. (2016). The Future of Resources: A New Chapter. New Global Studies, årg. 10(2), s. 133-161. https://doi.org/10.1515/ngs-2016-0013

Bærebo (2019). Tilgængelig på: https://www.baerebo.org/ [Tilgået d. 2. december 2019] Dawson, J. (2013). From Islands to Networks. The History and Future of the Ecovillage Movement. I: Lockyer, J. og Veteto, J.R., red., Environmental Anthropology Engaging Ecotopia: Bioregionalism, Permaculture, and Ecovillages. New York, USA: Berghahn Books, Incorporated.

Della Porta., D., Diani, M., Rootes, C. og Nulman, E. (2015). The Impacts of Environmental Movements. I: Della Porta, D. og Diani, M., red., The Oxford Handbook of Social Movements. New York: Oxford University Press. https://doi.org/10.1093/oxfordhb/9780199678402.013.55

Dobson, A. (2007). Environmental citizenship: towards sustainable development. Sustainable Development, årg. 15(5), s. 276-285. https://doi.org/10.1002/sd.344

Doherty, B. (2002). Ideas and Actions in the Green Movement. London, UK: Routledge. https://doi.org/10.4324/9780203994108

DR P1 Radio (2018). Klimatestamentet. P1. Tilgængelig på: https://www.dr.dk/radio/p1/klimatestamentet [Tilgået d. 15. juli 2019].

Ecolise (2019). Reshaping the Future: Executive Summary. The First Status Report on Community-led Action on Sustainability and Climate Change in Europe. How local communities are catalysing social, economic and ecological transformation in Europe. Tilgængelig på https://www.ecolise.eu/wp-content/uploads/2016/02/Executive-Summary-Status-Report-on-Community-led-Action-onSustainability-and-Climate-Change-in-Europe-2019-.pdf [Tilgået d. 16. juli 2019].

EcoVillage (2019). Tilgængelig på: https://www.eco-village.dk/ [Tilgået d. 2. december 2019]

Eriksen, T.H. (2016). Overheating: the world since 1991. History and Anthropology, årg. 27(5), s. 469-487. https://doi.org/10.1080/02757206.2016.1218865

Gausset, Q. og Tjørring, L. (2016). Energy Renovation models in Private Households in Denmark. I: Gausset, Q. og Hoff, J., red, Community governance and citizen driven initiatives in climate change mitigation, Routledge advances in climate change research. London, New York: Routledge. https://doi.org/10.4324/9781315700298-6 
Gausset, Q. (2019). Stronger together: how Danish environmental communities influence behavioural and societal changes. I: J. Hoff, Q. Gausset og S.W. Lex, red, Building a sustainable future. The role of non-state actors in the green transition. London: Routledge. https://doi.org/10.4324/9780429280399

GEN (2017). Samtale med daværende præsident for Global Ecovillage Network Daniel Greenberg ved workshop på GEN-konference i Ängsbacka, Sverige (21. juli 2017).

GEN (2019a). Global Ecovillage Network. Tilgængelig på: www.ecovillage.org/ [Tilgået d. 15. juli 2019].

GEN (2019b). Dimensions of Sustainability. Tilgængelig på: https://ecovillage.org/projects/dimensions-of-sustainability/ [Tilgået d. 9. oktober 2019].

Haenfler, R., Johnson, B. og Jones, E. (2012). Lifestyle Movements: Exploring the Intersection of Lifestyle and Social Movements. Soc. Mov. Stud. årg. 11(1), s. 1-20. https://doi.org/10.1080/14742837.2012.640535

Hansen, A.H. (2019). It has to be reasonable: pragmatic ways of living sustainably in Danish eco-communities. I: J. Hoff, Q. Gausset og S.W. Lex, red., The Role of Non-State Actors in the Green Transition: Building a Sustainable Future. London: Routledge. https://doi.org/10.4324/9780429280399

Hoff, J. og B. W. Strobel (2013). A Municipal 'Climate Revolution'? The Shaping of Municipal Climate Change Policies'. The Journal of Transdisciplinary Environmental Studies, årg. 12(1), s. 3-14.

Hoff, J. og M. Islar (2019). Are Vegetables political? The traces of the Copenhagen Food Coop. I: Hoff, J., Gausset, Q. og Lex, S., red., The Role of Non-State Actors in the Green Transition: Building a Sustainable Future. London: Routledge. https://doi.org/10.4324/9780429280399

Hoff, J., Gausset, Q. og Lex, S. (2019). Introduction. I: Hoff, J., Gausset, Q., Lex, S., red., The Role of Non-State Actors in the Green Transition: Building a Sustainable Future. London: Routledge. https://doi.org/10.4324/9780429280399

Jamison, A., Eyerman, R. og Cramer, J. (1990). The making of the new environmental consciousness, a comparative study of the environmental movements in Sweden, Denmark and the Netherlands. Edinburgh: Edinburgh University Press.

Jensen, K. M., Jensen, P. D. og Hansen, A. H. (2019). Strukturer skaber en bæredygtig hverdag. I: Q. Gausset, K. H. B. Jensen og J. B. Hunt, red., VIGØR - Fortcellinger fra den grønne frontlinje. Danmark: Ingerfair.

Kamieniecki, S. (1993). Environmental Politics in the International Arena: Movements, Parties, Organizations, and Policy. SUNY Press.

Krøijer, S. (2019). Slow Rupture: The Art of Sneaking in an Occupied Forest. I: Holbraad, M. Kapferer, B. og Sauma, J., red., Ruptures: Anthropologies of Discontinuity in Times of Turmoil. London: University College London.

Latour, B. (2008). En ny sociologi for et nyt samfund, introduktion til aktør-netvork-teori. Kbh.: Akademisk. Oversat af Claus Bratt Østergaard. 
Litfin, K.T. (2014). Ecovillages, Lessons for Sustainable Community. 1st ed. Somerset: Polity Press.

Lockyer, J. og Veteto, J.R. (2013). Environmental Anthropology Engaging Ecotopia: Bioregionalism, Permaculture, and Ecovillages. New York, USA: Berghahn Books, Incorporated.

Lovell, H.C. (2012). Eco-communities. I: Smit, S., red., International Encyclopedia of Housing and Home Spain. Amsterdam: Elsevier, s. 1-5. https://doi.org/10.1016/b978-0-08-047163-1.00600-7

LØS (2016). En bæredygtig omstilling af Danmark. Strategi 2016-2019. Tilgængelig på: http://okosamfund.dk/wp-content/uploads/En-b\%C3\%A6redygtig-omstilling-afDanmark-L\%C3\%98S-strategi-2016.pdf [Tilgået d. 9. oktober 2019].

LØS (2018). Privat samtale med daværende medlem af LØS' bestyrelse Niels Aagaard. (3. april 2018).

LØS (2019). Landsforeningen for Økosamfund. Tilgængelig på: http://okosamfund.dk/vi-er/ [Tilgået 9. oktober 2019].

Marckmann, B. (2009). Hverdagslivets kritik: økosamfund i Danmark. Ph.d.-afhandling, nr. 53. Sociologisk Institut. København: Københavns Universitet.

Marckmann, B., Gram-Hanssen, K. og Christensen, T.H. (2012). Sustainable Living and Co-Housing: Evidence from a Case Study of Eco-Villages. Built Environment, årg. 38(3), s. 413-429. https://doi.org/10.2148/benv.38.3.413

McKay, G. (1998). DiY culture, party \& protest in Nineties Britain. London: Verso.

Miller, F. (2018). Ecovillages around the World: 20 Regenerative Designs for Sustainable Communities. Rochester, VT: Findhorn Press.

Reinholdt, L. (1997). Boscetningseksperimenter. Danmark: Svanholm Forlag.

Scavenius, T. (2016). The Tragedy of the Few. Res Publica, bind. 22(1), s. 53-65. https://doi.org/10.1007/s11158-015-9311-0

Scheidel, A., Temper, L., Demaria, F. og Martínez-Alier, J. (2018). Ecological distribution conflicts as forces for sustainability: an overview and conceptual framework. Sustainability Science, årg. 13(3), s. 585-598. https://doi.org/10.1007/s11625017-0519-0

Tsing, A.L. (2005). Friction: An Ethnography of Global Connection. Princeton, USA: Princeton University Press.

Udlændinge-, Integrations- og Boligministeriet (2016). Fremtidens bofcellesskaber i funktionstømte bygninger $i$ storbyen, provinsbyen og på landet. Denmark: Dansk Bygningsarv.

Wapner, P. (1995). Politics beyond the State Environmental Activism and World Civic Politics. World Politics, årg. 47(3), s. 311-340. https://doi.org/10.1017/s0043887100016415 